\title{
The Investigation of True and a Focal Zoom-Lens Properties of Five-Element Cylindrical Electrostatic Lens
}

\author{
Nedhal S. A-Hujazie \\ Basic Science Branch \\ College of Agriculture \\ Mosul University \\ nedhal_sadie2000@yahoo.com
}

\author{
Marwa T. Al-Shamma \\ Department of Physics \\ College of Science \\ Mosul University \\ benqmarwa@yahoo.com
}

\author{
Zahra M. Al-Hialey \\ Department of Electric \\ Technical Institute \\ Mosul
}

(Received 28/12/2009 ; Accepted 15/3/ 2010)

\begin{abstract}
In the present work , a computational investigation has been considered on the true and a focal zoom-lens (i.e. lenses whose magnification may be changed without losing focus)for the five-cylindrical electrostatic lens system, by the aid of the simulation program LENSYS, using the finite difference method .Results are obtained as a function of the ratio of the controlling voltages. It was found that the five-cylindrical lens can be operated with the whole focus properties in a useful mode for controlling and focusing the charged particles in experimental studies.
\end{abstract}

Keywords: electrostatic lenses, zoom- lens properties , LENSYS.

السقصاء الخواه الهققية والبؤربة الزومية لالمسك الكهروستاتيكية الخملسية

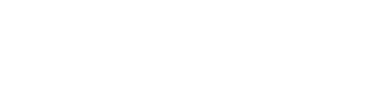

\section{الملغص}

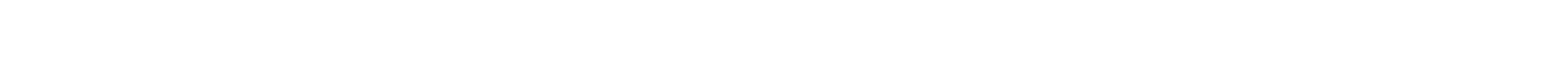
اللنطوانية وبلستخدل إحدى برلمج المحلكة والمعروف بلس م ( LENSYS ) ). وال ذي يـ ستخدمطريق ة الفروقلت المتناهية. دسنت النتائج كدالة للفولتية المسيطرة، وقد وجد بلن هذه العهسة بالإمكان تشغيلها بكالفة خواصها البؤرية في نمط معين لأجل اللسطرة وتبؤر الحزم المشحونة والمستخدة في الدرلسلت العملية.

الكاملت الدالة : العهلت الكهروستاتيكية، خواص العهسة الزومية ، LENSYS . 